\title{
ANALYSIS OF EDGAR ALLAN POE'S THE TELLTALE HEART BASED ON SPEECH ACT THEORY
}

\author{
Nina Rostina ${ }^{1}$, Asri Pratiwi Mulandari ${ }^{2}$ \\ ${ }^{1}$ IKIP SILIWANGI \\ ${ }^{2}$ IKIP SILIWANGI \\ 1ninaros96@gmail.com, 2assrimulandarii@gmail.com
}

\begin{abstract}
This research is analyzing short story "The Tell-tale Heart" by Edgar Allan Poe based on speech act. Speech act consists of categories; representatives, directives, expressive, commissive, and declaratives. Researcher focused on representative speech act. This concerns fictional character of this story as a narrator who utters his belief toward situation he faced. A total of 128 utterances is analyzed and divided into categories of boasting, asserting, stating, informing, claiming, complaining, concluding, criticizing, reporting, describing, suggesting, swearing, and denying. Th result of this research has revealed that $39 \%$ representative speech act of reporting category is the most frequently used in the short story while the least including criticizing with $1 \%$. This story is the perfect example of picturing representative speech act while not so many genres do so. By observing some points of utterances, reader will commence to understand the structure of speech act.
\end{abstract}

Keywords:Speech Act, Short Story, The Tell Tale Heart.

\section{INTRODUCTION}

Language is a tool of social interaction or a means of human communication. As the ultimate communication tool, language is able to reveal some information about feelings, thoughts, ideas, intentions and emotions directly. So the language is able to express a meaning can even mean doing an action, the action was then known as speech act (speech act).Speech acts theory was first introduced in 1975 by (J.L, 1962), a professor at Harvard University, in "How to Do Things With Words".

This analysis will focus on representative speech act along with the explanation of locutionary, illocutionary and perlocutionary act, because they are the main points of speech act. The source of data collection will be the short story written by Edgar Allan Poe. Edgar Allan Poe himself is one of the best writers ever. Edgar Allan Poe's short story is quite interesting to be analyzed since the fictional characters of his short stories, had specific characteristic speech act regarding to the unusual theme of dark psychology. Due the reason, this study will analyze "The Tell-tale Heart" by Edgar Allan Poe Based on Representative Speech Act Theory. Fictional character of the "The Tell-tale Heart" was a narrator who explicitly expressed his belief which form of representative speech act.

This research is intended to make readers understand more about representative speech act. The reader can notice why this short story consists of representative speech act more than the other four types. In Principles of Pragmatics, the terminologies from (J.L, 1962), the types of speech acts are locutionary act, illocutionary act, and perlocutionary act. 


\section{Illocutionary Act}

In speech act theory, the listener is seen as playing a passive role. The illocutionary force of a specific utterance is determined with regard to the linguistic form of the utterance and also self-analysis as to whether the necessary felicity conditions not least in relation to the utterer's beliefs and feelings are fulfilled. Interactional aspects are, thus, neglected. However, conversation is not just a more chain of independent illocutionary forces, speech acts are connected to other speech acts with a wider discourse context. Speech act theory, in that it does not contemplate the function played by utterances in driving conversation is, therefore, insufficient in accounting for what actually occurs in conversation." (Barron, 2003).

\section{Locutionary Act}

Locutionary act is the act of simply uttering a sentence from a language; it is description of what the utterer says (Leech, 1983). Illocutionary act is the act in which the speaker aims to do something by producing an utterance. Illocutionary acts would contain stating, promising, thanking, congratulating, apologizing, threatening, predicting, ordering, and requesting (Leech, 1983). For example, if a girl says to her friend, "Take my bag!" the illocutionary act is the act of ordering. Illocutionary acts, unlike locutionary acts, are very hard to understand.

\section{Perlocutionary Act}

Perlocutionary act is the act done by the listener exaggerated by what the speaker has said. Perlocutionary acts would contain effects such as: get the hearer to think about, bring the listener to learn that, get the listener to do, persuading, embarrassing, intimidating, boring, irritating, or motivating the listener (Leech, 1983). For the example if the father utters this sentence to his school-age son, "You'd better do your homework", in that utterance the perlocutionary act might be one of irritating, especially if this speech act is a daily manifestation.

\section{The Function of Speech Acts}

Conferring to Searle (1979) in (Yule, 1996), the five general functions accomplished by speech act are:

a. Representatives are those types of speech acts that state what the utterer trusts to be the situation or not. In consuming a representatives, the utterer makes words fit in the world (of believe). i.e. stating, suggesting, boasting, asserting, describing, complaining, claiming, informing, concluding, criticizing, denying swearing and reporting.

b. Directives are those types of speech acts that speakers use to acquire somebody else to prepare something (express what the utterers want). The utterers efforts to make the world fit via the hearer. i. e. commanding, requesting, advising, recommending, and ordering.

c. Commissives are those types of speech acts that utterers use to obligate themselves to several upcoming action (express what the speaker intends). i. e. vowing, offering, threatening, promising.

d. Expressives are those types of speech acts that state what the utterer senses (express psychosomatic circumstances and can be statement of pleasure, pain, likes, dislikes, joy, or sorrow. The utterer uses an expressive to make fit the world (of feeling). i. e. thanking, congratulating, pardoning, blaming, praising, condoling etc. 
e. Declarations are those types of speech acts that change the world via utterance. It means that the utterer must have a specific institutional role, in specific contexts, to show declarations accurately.

This table further down will give a brief understanding about the relationship between speech act types and language functions, which was following Searle's though. (Yule, 1996).

Table 1. Relationship between Speech Act Types and LanguageFunctions

\begin{tabular}{lll}
\hline Speech Act Type & Direction of fit & $\begin{array}{l}\text { S=speaker; } \\
\text { X=situation }\end{array}$ \\
\hline Representative & Make words fit the world & S believes X \\
\hline Directive & Make the world fit world & S wants X \\
\hline Commissive & Make the world fit words & S intends X \\
\hline Expressive & Make words fit the world & S feels X \\
\hline Declaration & Words change the world & S causes X
\end{tabular}

The individuals communicate to each other must consider with the function of speech act, it can be seen from description above. When individuals make communication with the other, the dialogs states to the expressives and the directives functions, meanwhile, the others functions are unrelated.

\section{METHOD}

This research uses a qualitative method. Method of this qualitative research is content analysis. Short story is specific object in this research. This type of research allow the research to consider the meanings that people attribute to their behavior, actions, and interactions with others. Method of this qualitative research is content analysis. This method is used to analyze by inferring words and images from documents, film, art, music, and other cultural products and media. Short story is specific object in this research. Observers look at how the words and are used, and the context in which they are used to imagine inferences about the underlying culture. The data were analyzed by using the grouping of representative speech act by (Yule, 1996). There were some steps as follows: Identifying the sentences found in The Tell-tale Heart. In doing analysis, for the first, the researchers identified the utterances to find representative speech act used by characters. Classify the utterances into the kinds of representative speech act. The utterances were analyzed created on the character of representative speech act. It is used to know which type the utterances belong to. Investigating the types of representative speech act that used dominantly by types. It was analyzed created on the choice of word and sentence used by types.

\section{RESULTS AND DISCUSSION}

\section{Results}

Below are the analyses of The Tell-tale Heart base on categories of representative speech acts.

\section{Boasting}

Boasting is talk with unnecessary conceit and self-satisfaction about one's achievements, possessions, or abilities. 
There are seven utterances spoken by the character. Among these boasting representative speech acts, six utterances can be classified as illocutionary as these speech acts reflect the intent of the utterer only. While one is under perlocutionary aspect because they bring about consequences to the readers. Researcher analyzed utterance the speaker or narrator in this case, by checking the respond while reading this story. Following are examples.

Table 2. Analysis of Boasting Utterance

\begin{tabular}{ccclcc}
\hline No. & Speaker & Hearer & \multicolumn{1}{c}{ Dialogue } & Illocutionary & Perlocutionary \\
\hline 1 & Narrator & Reader & $\begin{array}{l}\text { The disease had sharpened } \\
\text { my senses, not destroyed, not } \\
\text { dulled them. }\end{array}$
\end{tabular}

\section{Asserting}

Asserting is to state belief confidently. There are four utterances spoken by narrator. Three utterances under the illocutionary aspect and one is perlocutionary aspect. Following are examples.

Table 3. Analysis of Asserting Utterance

\begin{tabular}{cccccc} 
No. & Speaker & Hearer & Dialogue & Illocutionary & Perlocutionary \\
\hline 1 & Narrator & Reader & $\begin{array}{l}\text { Now you may think that I drew } \\
\text { back, but no. }\end{array}$ & $\sqrt{ }$ \\
\hline 2 & Narrator & Reader & I smiled, for what had I to fear? & $\sqrt{ }$ & \\
\hline
\end{tabular}

\section{Stating}

Stating is to express something definitely or clearly in speech or writing. They are five stating and two of them under illocutionary aspect while the other three are under prelocutionary aspect. Following are example.

Table 4. Analysis Stating Utterance

\begin{tabular}{cccccc}
\hline No. & Speaker & Hearer & \multicolumn{1}{c}{ Dialogue } & Illocutionary & Perlocutionary \\
\hline 1 & Narrator & Reader & Madmen know nothing. & $\sqrt{ }$ & \\
\hline 2 & Narrator & Police & $\begin{array}{l}\text { "Dissemble no more! I admit } \\
\text { the deed! Tear up the planks! } \\
\text { Here, here! }\end{array}$ & & $\sqrt{ }$ \\
\hline
\end{tabular}

\section{Informing}

Informing is to give information There are three utterances of informing and all of them under illocutionary aspect. Following are examples. 
Table 5. Analysis of Informing Utterance

\begin{tabular}{|c|c|c|c|c|c|}
\hline No. & Speaker & Hearer & Dialogue & Illocutionary & Perlocutionary \\
\hline 1 & Narrator & Reader & Now this is the point. & $\sqrt{ }$ & \\
\hline 2 & Narrator & Reader & $\begin{array}{l}\text { I was never kinder to the old } \\
\text { man than during the whole } \\
\text { week before I killed him. }\end{array}$ & $\sqrt{ }$ & \\
\hline
\end{tabular}

\section{Claiming}

Claiming is to state or assert that something is the case, typically without providing evidence or proof. There are twelve utterances of claiming. One of them is under perlocutionary aspect and the other eleven are under illocutionary aspect. Following are examples.

Table 6. Analysis of Claiming Utterance

\begin{tabular}{llllll}
\hline No. & Speaker & Hearer & \multicolumn{1}{c}{ Dialogue } & Illocutionary & Perlocutionary \\
\hline 1 & Narrator & Reader & $\begin{array}{l}\text { Never before that night had I felt the } \\
\text { extent of my own powers of my } \\
\text { sagacity. }\end{array}$ & $\sqrt{ }$ & \\
\hline 2 & Narrator & Reader & You fancy me mad. & $\sqrt{ }$ \\
\hline
\end{tabular}

\section{Complaining}

Complaining is to express dissatisfaction or annoyance about a state of affairs or an event. There are four utterances of complaining and all of them under illocutionary aspect. Following are examples.

Table 7. Analysis of Complaining Utterance

\begin{tabular}{|c|c|c|c|c|c|}
\hline $\begin{array}{c}\text { No } \\
\text {. }\end{array}$ & Speaker & Hearer & Dialogue & Illocutionary & Perlocutionary \\
\hline 1 & Narrator & Reader & Why would they not be gone? & $\sqrt{ }$ & \\
\hline 2 & Narrator & Reader & $\begin{array}{l}\text { But anything was better than this } \\
\text { agony! Anything was more tolerable } \\
\text { than this derision! I could }\end{array}$ & $\sqrt{ }$ & \\
\hline
\end{tabular}

\section{Concluding}

Concluding is to bring something to an end or arrive at a judgment or opinion by reasoning. There are five utterances of complaining and all of them are under illocutionary aspect. Following are examples.

Table 8. Analysis of Concluding Utterance

No. Speaker Hearer Dialogue Illocutionary Perlocutionary




\begin{tabular}{llll}
\hline 1 Narrator Reader & $\begin{array}{l}\text { I made up my mind to take the } \\
\text { life of the old man, and thus rid } \\
\text { myself of the eye forever. }\end{array}$ & $\sqrt{ }$ \\
\hline 2 Narrator Reader & $\begin{array}{l}\text { At length it ceased. The old } \\
\text { man was dead. }\end{array}$ & $\sqrt{ }$ \\
\hline
\end{tabular}

\section{Criticizing}

Criticizing is to indicate the faults of somebody or something in a censorious way. There is only an utterance in this category and is under perlocutionary aspect. Following is the utterance.

Table 9. Analysis of Critizing Utterance

\begin{tabular}{cccccc}
\hline No. & Speaker & Hearer & Dialogue & Illocutionary & Perlocutionary \\
\hline 1 & Narrator & Reader & But you should have seen me. & $\sqrt{ }$ \\
\hline
\end{tabular}

\section{Reporting}

Reporting is to provide a spoken or written account of something that one has experimental, heard, done, or investigated. There are fifty utterances under this category. All is under illocutionary aspect. Following are examples.

Table 10. Analysis of Reporting Utterance

\begin{tabular}{ccclc}
\hline No. Speaker & Hearer & \multicolumn{1}{c}{ Dialogue } & Illocutionary & Perlocutionary \\
\hline 1 & Narrator & Reader & $\begin{array}{l}\text { First of all I dismembered the } \\
\text { corpse. I cut off the head and } \\
\text { the arms and the legs. }\end{array}$ & $\sqrt{ }$ \\
\hline & & $\begin{array}{l}\text { I foamed, I raved, I swore! I } \\
\text { swung the chair upon which I } \\
\text { had been sitting, and grated it } \\
\text { upon the boards, but the noise } \\
\text { arose over all and continually } \\
\text { increased. }\end{array}$ & $\sqrt{ }$ \\
\hline
\end{tabular}

\section{Describing}

Describing is togive an account in words of someone or something, including all the relevant characteristics, qualities, or events.

There are around thirty two utterances in this category. All of them are under illocutionary aspect. Following are examples.

Table 11. Analysis of Describing Utterance

\begin{tabular}{ccccc} 
No. Speaker & Hearer & Dialogue & Illocutionary & Perlocutionary \\
\hline 1 & Narrator & Reader & $\begin{array}{l}\text { It is impossible to say how first } \\
\text { the idea entered my brain; but } \\
\text { once conceived, it haunted me } \\
\text { day and night. }\end{array}$ & $\sqrt{ }$ \\
\hline
\end{tabular}


His room was as black as pitch with the thick darkness, (for the

2 Narrator Reader shutters were close fastened, through fear of robbers,) and so I knew that he could not see the opening of the door.

\section{Suggesting}

Suggesting is toput forward for consideration or cause one to think that something exists or is the case. There are three utterances of suggesting. All of them are under prelocutionary aspect. Following are examples.

Table 12. Analysis of Suggesting Utterance

\begin{tabular}{ccclcc}
\hline No. Speaker & Hearer & \multicolumn{1}{c}{ Dialogue } & Illocutionary & Perlocutionary \\
\hline 1 & Narrator & Reader & $\begin{array}{l}\text { Hearken! and observe how } \\
\text { healthily, how calmly I can tell } \\
\text { you the whole story. }\end{array}$ & $\sqrt{ }$ \\
\hline & & $\begin{array}{l}\text { You should have seen how } \\
\text { wisely I proceeded, with what } \\
\text { caution, with what foresight, } \\
\text { with what dissimulation I went } \\
\text { to work! }\end{array}$ & $\sqrt{ }$ \\
\hline
\end{tabular}

\section{Swearing}

Swearing is tomake a solemn statement or promise. There is an utterance of swearing and it is under the illocutionary aspect. Following is the utterance.

Table 13. Analysis of Swearing Utterance

\begin{tabular}{|c|c|c|c|c|c|}
\hline No. & Speaker & Hearer & Dialogue & Illocutionary & Perlocutionary \\
\hline 1 & Narrator & Reader & Almighty God! & $\sqrt{ }$ & \\
\hline
\end{tabular}

\section{Denying}

Denying isstate that one refuses to admit the truth or existence of or to refuse to admit the truth. There is only an utterance of denying and is under prelocutionary aspect. Following is the utterance.

Table 14. Analysis of Denying Utterance

\begin{tabular}{|c|c|c|c|c|c|}
\hline No. & Speaker & Hearer & Dialogue & Illocutionary & Perlocutionary \\
\hline 1 & Narrator & Reader & $\begin{array}{l}\text { And have I not told you that } \\
\text { what you mistake for madness } \\
\text { is but over-acuteness of the } \\
\text { sense? }\end{array}$ & & $\sqrt{ }$ \\
\hline
\end{tabular}




\section{DISCUSSION}

Based on the analysis above, Following is the summary of representative speech act occurrences in the short story text. These are summarized in the form of a table.

Table 15. The Sumary of Representative Speech Act Occurrences

\begin{tabular}{clccc}
\hline \multirow{2}{*}{ NO } & \multirow{2}{*}{$\begin{array}{c}\text { Directive Speech Act } \\
\text { Sub-Categories }\end{array}$} & \multicolumn{2}{c}{ Frequency } & Percentage \\
\cline { 3 - 4 } & & Illocutionary & Perlocutionary & \\
\hline 1 & Boasting & 6 & 1 & $5.5 \%$ \\
2 & Assert & 3 & 1 & $3.1 \%$ \\
3 & Stating & 2 & 3 & $3.9 \%$ \\
4 & Informing & 3 & 0 & $2.3 \%$ \\
5 & Claiming & 11 & 1 & $9.4 \%$ \\
6 & Complaining & 4 & 0 & $3.1 \%$ \\
7 & Concluding & 5 & 0 & $3.9 \%$ \\
8 & Criticizing & 0 & 1 & $0.8 \%$ \\
9 & Reporting & 50 & 0 & $39.0 \%$ \\
10 & Describing & 32 & 0 & $25.0 \%$ \\
11 & Suggesting & 0 & 3 & $2.3 \%$ \\
12 & Swearing & 1 & 0 & $0.8 \%$ \\
13 & Denying & 1 & 0 & $0.8 \%$ \\
\hline \multicolumn{2}{r}{ Total } & $\mathbf{1 1 8}$ & $\mathbf{1 0}$ & $\mathbf{1 0 0 . 0 \%}$ \\
\hline
\end{tabular}

The table of summary shows that representative speech acts are presented for 128 times throughout the short story. The most frequently used illocutionary aspect in reporting and describing sub-categories. Researcher did not find any illocutionary aspect under suggesting. The most frequently used perlocutionary aspect is in stating and suggesting. The most frequently used sub-category of representative speech act is reporting with $39.0 \%$ and the least used sub-categories in this short story is criticizing, swearing and denying with both $0.8 \%$.

\section{Representative Speech Act and Human Beliefs}

Representative speech act represents beliefs of the speaker, the narrator in this case. Not so many explanations about this speech act, but the researcher find it's unique. One of them is that the representative speech act contains somewhat quite humanize. All humans have beliefs, which are concepts they hold to be true, even without evidence. Beliefs can be quite helpful to us in many ways. Human belief systems are complex and diverse, and so they often come into conflict. Most people have little intuition into what ignites their day-to-day behavior, conferring to scientific indication. In aggregate, these self-beliefs determine the direction and intensity of our motivated action. The beliefs determine what we do, how we do it, and how we realize our undertaking in relation to the rest of the world.

The representative speech act hold and importance, say, to put their beliefs into both written text such a literature and verbal. This type of speech act is fit to be used in literature contains presentation of the writers and character's point of views. 


\section{CONCLUSION}

The analysis leads to the following conclusion. The Tell-tale Heart, despite of being everlasting piece of literature, contains utterances that most of them are categorized as representative speech act. The plot is ideal to used representative speech act since this story plot is brought by a narrator who uttered his beliefs while he let the reader evaluate whether those were true or not about his states. Out of the summary, from 128 utterances, 39\% representative speech act of reporting is the furthermost regularly used in the short story while the least including criticizing with $1 \%$.

The way the character or narrator uttered their beliefs is interesting in many ways. Representative speech act cannot be divided from both daily information and literatures. This story is the perfect example of picturing representative speech act while not so many genres do so. By observing some points of utterances, reader will commence to understand the structure of speech act. This piece is also contains contemporary language which brings the shades of the period when the writer and or narrator lives.

The researcher would like to offer some suggestion. First, many readers can learn language skill from older literatures directly by reading through. Second, reader can observe the link between utterances and psychological issues character has though not too palpable and there was no specific explanation and also further researches are needed. Third, this method of learning can be useful in language class, since the material and language used is authentic. The fact, benefits of reading is quite unlimited.

\section{ACKNOWLEDGMENTS}

In the name of Allah, The Beneficent, The Merciful. All praised be to Allah, Lord of the world, who has given the author His blessing, compassion, and strength to finish this paper. Without the strength, which was given by Allah SWT, this task would never finish. Peace and salutation be upon to the prophet Muhammad SAW, his family, his companions, and his followers.

In this occasion, authors would like to express gratitude to honorable Hendra Husnussalam.S.S M.Hum for all the precious and uncountable time, advice, suggestions, comments, motivation, and support during the process of doing this paper.

Next, the author also wants to express her appreciation goes to the institution who helped her to finish this assignment.

\section{REFERENCES}

Barron, A. (2003) Acquisition in Interlanguage Pragmatics: Learning How to Do Things With Words in a Study Abroad Contexct John Benjamins.

J.L, A. (1962) How to do Things with Word. Oxford: Oxford University Press.

Leech, G. (1983) Principles of Pragmatics. London: Longman.

Yule, G. (1996) Pragmatics. New York: Oxford University Press. 